\title{
ДОСВІД ЗАСТОСУВАННЯ СУЧАСНИХ МОДИФІКОВАНИХ ОСВІТНІХ МЕТОДИК У СТУДЕНТІВ ДИСТАНЦЙНОӦ ФОРМИ НАВЧАННЯ
}

\author{
Л. П. Мазур, С. О. Коноваленко \\ ДВНЗ “Тернопільський державний медичний університет імені \\ I. Я. Горбачевського МОЗ Украӥни”
}

\section{EXPERIENCE OF MODERN MODIFIED EDUCATIONAL TECHNIQUES USAGE IN THE STUDENTS OF DISTANCE LEARNING}

\author{
L. P. Mazur, S. O. Konovalenko \\ SHEI "Ternopil State Medical University by I. Ya. Horbachevsky of MPH of Ukraine"
}

\begin{abstract}
У статті представлені дані щодо особливостей організації навчального процесу у студентів дистанційної форми навчання, спеціальності “Сестринська справа” - бакалаврів та магістрів і використання системи Мооде для проведення поточного й екзаменаційного контролю знань. Визначені основні проблеми, які виникають при засвоєнні матеріалу он-лайн та оцінюванні знань студентів, і висвітлені шляхи їх вирішення.
\end{abstract}

The article presents data regarding peculiarities of the studying process in students of the distant form of learning, speciality "Nursing" - bachelors and masters, and usage of the Moodle system for the providing of current and exam control of their knowledge. Also are shown the main problems, which appears during the on-line learning and evaluation of students` knowledge, and are highlighted ways of these problems` resolution.

Вступ. На сучасному етапі розвитку одним із найважливіших шляхів вдосконалення освіти $€$ широке впровадження інформаційно-комунікаційних технологій, що стало можливим в умовах бурхливого розвитку Інтернету та загальної комп'ютеризації населення [1].

Дистанційна, або он-лайн освіта, яка $є$ досить поширеною у різних країнах світу, - це одна із форм навчання, запровадження якої стало можливим із розвитком та доступністю інтернет-технологій. Дистанційна освіта $€$ новиною в Україні, проте це вже давно розроблений концепт за кордоном. Основною перевагою дистанційної форми навчання для медичних сестер за необхідності постійного підвищення ними професійної кваліфікації є її застосування без припинення робочого процесу, тобто вона $€$ максимально доступною для кожного.

Проте за умови проведення дистанційного навчання значно обмежується безпосереднє спілкування студента 3 викладачем, що вимагає пошуку нових шляхів взаємодії та вдосконалення якості забезпечення освітнього процесу. Зокрема, покращення якості освіти значною мірою досягається застосуванням у повсякденному навчальному процесі контролю успіш-

(с) Л. П. Мазур, С. О. Коноваленко ності навчальних досягнень студентів засобами систем комп'ютерного тестування $[2,3]$.

Основна частина. Вивчивши американський та європейський досвід з впровадження дистанційної (он-лайн) системи навчання та заручившись підтримкою МОЗ та МОН України, на базі ДВНЗ “Тернопільський державний медичний університет імені І. Я. Горбачевського МОЗ України" в 2008 році було запроваджено дистанційну форму навчання для медсестер освітньо-кваліфікаційного рівня “Бакалавр", а 32010 року медичні сестри отримали змогу здобувати вищу освіту за ОКР "Магістр” за такою ж формою навчання.

В 2013-2014 навчальному році за дистанційною формою в ТДМУ вже навчалися 425 студентів, 3 них 256 - іноземні громадяни (рис. 1).

На даний час навчання бакалаврів здійснюється українською (громадяни України), російською та англійською (іноземні громадяни) мовами, а магістрів - українською (громадяни України) та англійською (іноземні громадяни) мовами.

Проведення дистанційного навчання в університеті здійснюється 3 використанням системи Moodle. 3 метою забезпечення максимальної доступності навчальних матеріалів для студентів при здійсненні дистанційного навчання впроваджено цикловий ме- 


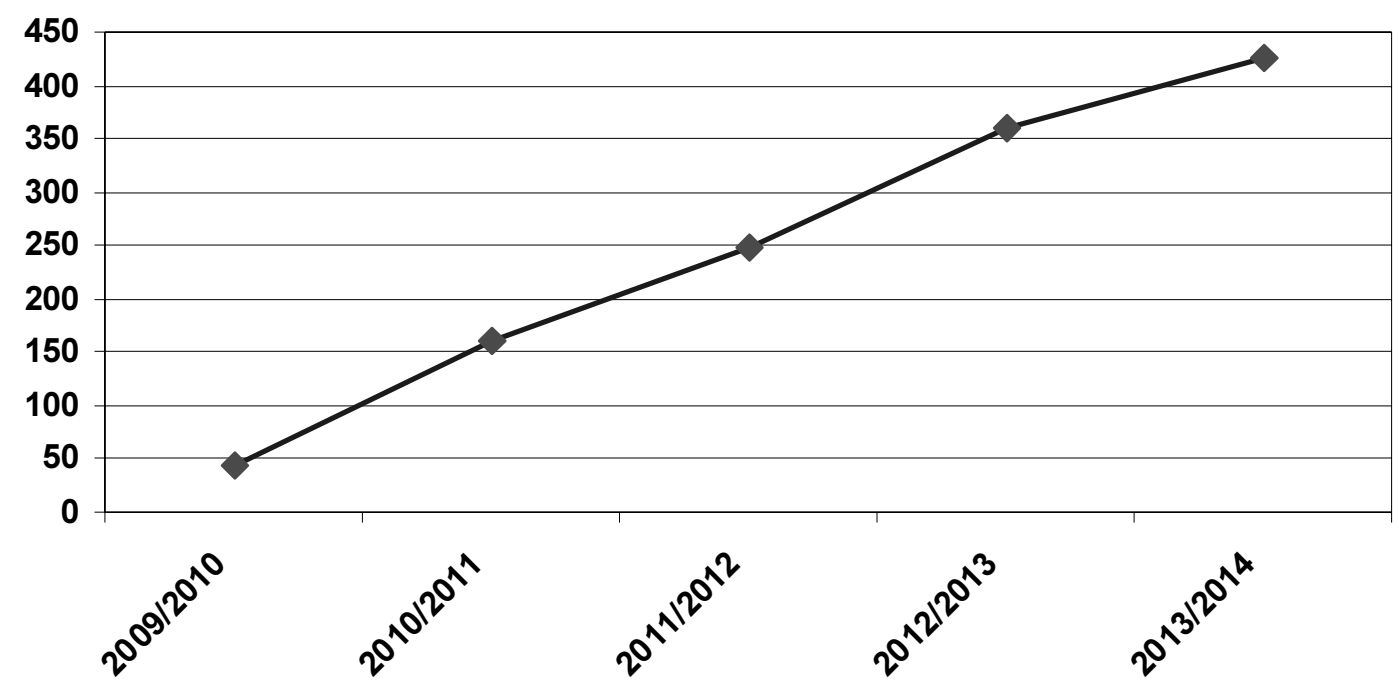

Рис. 1. Динаміка кількості студентів дистанційної форми навчання в ТДМУ.

тод. В перші дні вивчення окремого предмета студенти прослуховують лекції, для чого виділені окремі лекційні дні на початку кожного предмета. Після засвоєння лекційного матеріалу проводяться практичні заняття тривалістю 6 годин кожне за методикою “єдиного дня", оскільки в рамках он-лайн навчання система 2-годинних пар є надто складною та недоцільною.

3 метою всебічного оцінювання знань студентів зі спеціальності “Сестринська справа” - бакалаврів та магістрів, які навчаються за дистанційною формою, застосовуються різноманітні методи контролю. Протягом практичного заняття студент отримує три оцінки - за практичну частину, семінар та тестування за темою заняття. Четверта оцінка є середнім арифметичним від попередніх трьох, а також-підсумковою за заняття.

Тестування визнано одним із найбільш об'єктивних методів оцінювання знань студентів, звільненим від будь-якого суб'єктивізму та впливу особистих уподобань викладача на результат оцінювання. Як один із компонентів оцінювання знань, тестування широко використовується при проведенні дистанційного навчання у студентів спеціальності “Сестринська справа". Проведення тестової частини заняття у студентів дистанційної форми навчання проводиться шляхом виконання тестових завдань у реальному часі у системі Moodle.

Для забезпечення проведення тестування на достатньому навчально-методичному рівні створені та укомплектовані бази тестових завдань із усіх предметів згідно з навчальним планом, та з усіх практич- них занять згідно з робочими програмами. Усі тестові завдання поділені на короткі тести, ситуаційні задачі та завдання із рисунками. При здачі тестування з наявної бази кожному студенту формується особистий білет, який містить 24 завдання. У ньому пропорційно закладаються завдання із трьох розділів. Таким чином, всі студенти отримують рівноцінні за ступенем складності білети.

Система Moodle дозволяє закласти у формулу оцінювання білета бажаний відсоток правильних відповідей та будь-яку шкалу, чи то 5-бальну, чи 12-бальну, чи 100-бальну. У системі Moodle в університеті запрограмована 12-бальна градація оцінювання знань студентів (тобто вартість кожного завдання у білеті становить 0,5 бала).

Кожному студенту надається одна спроба здачі тестування в рамках одного заняття. Слід зауважити наявні відмінності між застосуванням дистанційного оцінювання знань у студентів денної форми навчання та студентів-дистанційників. Так, перші проходять тестування напередодні проведення практичного заняття у чітко визначений графіком час - 30 хвилин. У разі, якщо такий студент отримує за тестування негативну оцінку чи бажає перездати тести на вищий бал - він має змогу зробити це на практичному занятті наступного дня під керівництвом викладача.

Водночас студенти дистанційної форми навчання проходять онлайн-тестування, перебуваючи у локальних центрах України та інших країн, та користуючись індивідуальними комп'ютерами. Зважаючи на великі віддалі та використання послуг різноманітних ком- 
паній-провайдерів, не завжди якість Інтернет-зв’ язку зі студентами є досконалою. Протягом 2013-2014 навчального року досить часто Інтернет-зв'язок із студентами-дистанційниками був неможливим протягом певного періоду часу у зв'язку із стихійними лихами. І такі ситуації виникають все частіше. Крім того, у ТДМУ навчаються студенти з різних континентів, і загалом вони знаходяться у часових поясах від GMT -7 год (Північна Америка) до GMT+2 год (Ізраїль). Усі студенти-дистанційники працюють, часто по змінах, що додатково вносить свої часові корективи. Тому тестування із певного практичного заняття для них активується на довший час, ніж для студентів денної форми навчання, і він становить 4 доби, починаючи, власне, із дня проведення заняття згідно з розкладом.

Нами проведено аналіз проходження онлайн-тестування у системі Moodle студентами дистанційної форми навчання. Слід відмітити, що найнижчі бали студентами були отримані з базових предметів (цикли гуманітарної, соціально-економічної та природничонаукової підготовки). У середньому успішність студентів по групах становила від 6,8 до 9,1 бала. Найвищі бали відмічені із предметів клінічного спрямування (цикл професійної та практичної підготовки), по групах це становило від 7,4 до 10,2 бала.

Пояснюємо цей факт тим, що студенти-дистанційники отримують в університеті не первинну освіту, а будучи чи то працівниками практичної охорони здоров'я, чи то викладачами медичних коледжів та училищ, - вдосконалюють свою професійну майстерність та здобувають дипломи вищого кваліфікаційного рівня. Теоретичні предмети для таких студентів є важкими у вивченні. Водночас при вивченні предметів практичного спрямування студенти не лише показують добрі знання, але й при спілкуванні з викладачами виказують свої міркування щодо вдосконалення тестових завдань із точки зору їхнього практичного досвіду.

\section{Література}

1. Закон України "Про Основні засади розвитку інформаційного суспільства в Україні на 2007-2015 роки" № 537-V від 09.01.2007 р. // Відомості Верховної Ради України. -2007 . - № 12. - С. 102.

2. Інформатика та комп'ютерна техніка. Частина I. Електронно-обчислювальні машини : навч. посіб. / Н. П. Ку-
Особливо важливою частиною роботи у системі Moodle $є$ проведення iз їі використанням перевідних екзаменаційних сесій у студентів-дистанційників. Згідно з навчальним планом, очно проходять лише державні іспити у студентів-бакалаврів та захист магістерських робіт - у студентів-магістрів. Проведення усіх інших іспитів проходить в онлайн-режимі згідно з графіком. Екзаменаційні білети формуються за тим же принципом, що і завдання для поточного контролю знань, та містять кількість запитань, кратну 12.

Поточна та екзаменаційна успішність як вітчизняних, так і студентів-іноземців не відрізняються суттєво (різниця у межах 1 бала). Також звертає не себе увагу вища успішність студентів із клінічних дисциплін порівняно з базовими теоретичними предметами. Крім того, слід відмітити у загальному дещо вищі оцінки за іспити порівняно з практичними заняттями. Це свідчить про те, що здаючи тестування для зарахування занять, студенти не лише проходять їх для контролю знань, але й оволодівають новою інформацією, яку потім з успіхом використовують при проходженні екзаменаційної сесії.

Для збільшення питомої частки очного спілування студентів із викладачами захист магістерських робіт студентів-іноземців з 2013 навчального року здійснюється із проведенням відеоконференції з викладачами ННI медсестринства із застосуванням технологіï Microsoft Lync, що дозволяє широко презентувати та обговорити результати наукових робіт.

Висновок. Таким чином, широке застосування системи дистанційного навчання Moodle $є$ виправданим, обгрунтованим і забезпечує високий рівень засвоєння навчального матеріалу, а також максимально об' єктивне та різнопланове оцінювання знань студентів. Тестовий контроль знань студентів дистанційної форми навчання слід визнати пріоритетним для визначення як поточної, так і екзаменаційної успішності.

харська, Т. Є. Рак, Р. О. Григорчук [та ін.]. - Львів : ЛДУ БЖД, 2011.-120 c.

3. Мясникова Т. С. Система дистанционного обучения MOODLE / T. C. Мясникова, С. А. Мясников. - Харьков, 2008.-232 c. 